\title{
Transitivity Analysis of A Rose for Emily
}

\author{
Zijiao Song \\ Changchun University of Science and Technology, Changchun, China
}

\begin{abstract}
Systemic Functional Linguistics (SFL) has been widely used by linguists and scholars to analyze linguistic phenomenon for many years. This paper adopts transitivity theory of SFL to study on the text of A Rose for Emily and analyze some processes in it and then explains their functions of constructing theme and shaping characters.
\end{abstract}

Index Terms - A Rose for Emily, systemic functional linguistics, transitivity, processes

\section{Systemic Functional Linguistics AND TRANSITIVITY}

Halliday holds that language has three metafunctions: ideational function, interpersonal function and textual function. Language in its ideational function represents patterns of experience of world and it enables human beings to build a mental picture of reality, to make sense of their experience of what goes on around them and inside them. This reflective experiential aspect of meaning is called transitivity (Hu \& Jiang, 2002).Transitivity is a grammatical system and it deals with different types of process which can be found in the language and the structures. Processes consist of process, participants and circumstances. There are six types of processes: (1) material processes, (2) mental processes, (3) relational processes, (4) behavioral processes, (5) verbal processes, and (6) existential processes.

Material processes are processes of doing which involves an Actor and often a Goal. The Actor means the one that does the deed, and the Goal implies directed act. Mental processes are processes of sensing which consist of two potential participants, Sensor and Phenomenon. Sensor is the conscious being that is feeling thinking or seeing. The phenomenon is what is sensed, felt, thought and seen. Mental processes can be divided into three subtypes: perception, affection and cognition. Relational processes are processes of being. There are three types of relational processes (1) intensive " $\mathrm{x}$ is a", (2) circumstantial " $\mathrm{x}$ is at a" and possessive " $\mathrm{x}$ has a", with the purpose to show the two kind of relationship between a and $\mathrm{x}$ : "a is an attribute of $\mathrm{x}$ " and "a is the identity of $\mathrm{x}$ ". Behavioral processes are of physiological and psychological behavior such as breath, dream, smile, cry, cough, etc which usually have one participant, the Behavior. Verbal processes are processes of saying which consist of three participants, the Sayer, the Receiver and the Verbiage. The Sayer is the addresser, the Receiver is the addressee and the Verbiage is the content of the message. Existential processes represent that something exists or happens. It is usually realized by there-construction (Hu \& Jiang, 2002).

TABLE1.

SIX TYPES OF PROCESSES

\begin{tabular}{|l|l|l|}
\hline Processes & Participants & Circumstances \\
\hline Material Processes & Actor-Process-Goal & Extent \\
\hline Mental Processes & Sensor-Process-Phenomenon & Manner \\
\hline Relational processes & Attributive or Identifying & Cause \\
& Carrier-Process-Attribute & Accompaniment \\
& Identified-Process-Identifier & Matter \\
\hline Behavioral processes & Behavior-process & \\
\hline Verbal Processes & Sayer-Process-Receiver-Verbiage & \\
\hline Existential Processes & Process-Existence & \\
\hline
\end{tabular}

\section{BRIEF INTRODUCTION TO A ROSE FOR EMILY}

William Faulkner is a famous American writer and Nobel Prize winner. He is well known for his novels and short stories. Faulkner is one of the most important writers in both American literature and Southern literature. He was born into a southern family, that's why his attitude toward the southern "aristocratic" families that he wrote about is ambiguous. Alongside his censure of their injustice to the African Americans, there is some indication of pity or sympathy (Chang, 2003).

A Rose for Emily is one of William Faulkner's famous short stories. The story takes place in Jefferson, Mississippi. Faulkner described the title as an allegorical title; the meaning was, here was a woman who has had a tragedy, a tragedy and nothing could be done about it, and I pitied her and this was a salute to a woman you would hand a rose. The story starts with an account of Emily Grierson's funeral. Then it presents in a nonlinear way the narrator's memories of Emily's strange and abnormal behaviors throughout her life. After the American civil war, Emily's life changes a lot. Both she and her father are unwilling to accept the changes, so they still remain to live the same life as what they were used to. Miss Emily keeps the strange manner of the Griersons, and she doesn't want to get away from the past, so she 
refuses to pay tax and successfully drives away the delegation that visits her for tax. Miss Emily seldom goes out the house or communicates with people in the town. When his father is alive, he stops all the young men pursuing his daughter because he looks down upon them since they are not aristocrats. When his father died, she spends three days to accept the fact. Two years after his father's death, she keeps a short love relationship with Homer Barron: a labor from the north comes to the town to build streets. But Homer is not a man who wants to get married, and he abandons her. The affair of smell comes into being. After that people in the town pay great attention to Emily's love with Homer and they interfere with her. Emily was found to buy the rat poison, the arsenic in a chemist store. People guess she is going to commit a suicide but in fact she goes much closer with Homer and she was seen to buy some men's living goods. When people think Emily is going to marry Homer, Homer disappears from the public sight. Emily begins to teach painting to make a living for six or seven years. As time passes by, Emily grows older and older and finally dies. When people go into her house, they find a skeleton of a man. It is Homer, and it turns out that Emily poisoned him. By using this cruel and strange way, Emily guards her love, the only love in her life.

\section{TRANSITIVITY ANALYSIS OF A ROSE FOR EMILY}

Many scholars have analyzed A Rose for Emily from the perspective of literary criticism. This paper will focus on the transitivity processes in the text and try to analyze some examples to present Emily's image of anti-tradition and pursuing love as well as people's emotion to Emily.

\section{A. Material Processes and Relational Processes}

Material processes and Relational processes are frequently found in the whole text, here only some of which are picked for deep analysis. The short story starts with the introduction to Miss Emily's death:

WHEN Miss Emily Grierson died, our whole town went to her funeral (Qian, 2011, p.337).

This sentence consists of two clauses. The first clause is a material process, the Actor is "Miss Emily Grierson" which is a polite and formal addressing, and this clause tells readers what happens at the beginning of the story. In the second clause, there is also a material process, here the Actor is our "whole town", and the Goal is "her funeral". As we all know that it is a custom to go to one's funeral after his or her death. The author uses "our whole town" as the Actor, instead of "we" or "people", so we can see Miss Emily's important status in the town. We can also infer that she must be a noble or famous person and she is respected by all the people there. The beginning sentence enables readers to go to the author's narration fast and be involved in the story as well as causes readers' curiosity about Miss Emily.

Then it follows with the description of Miss Emily's house.

It was a big, squarish frame house that had once been white, decorated with cupolas and spires and scrolled balconies in the heavily lightsome style of the seventies, set on what had once been our most select street. But garages and cotton gins had encroached and obliterated even the august names of that neighborhood; only Miss Emily's house was left, lifting its stubborn and coquettish decay above the cotton wagons and the gasoline pumps-an eyesore among eyesores(Qian,2011,p.338).

This paragraph consists of three sentences. The first sentence includes four processes: two relational processes and two material processes. Both the two Carriers are the "house", and the Attributes are "a big, squarish frame" and "white". The verb "decorate" is a transitive verb, but it is followed by a Circumstance: "cupolas and spires and scrolled balconies in the heavily lightsome style of the seventies" to present the outlook of the house and here house is the Goal of the process. The verb "set on" is followed by a Circumstance of location: "what had once been our most select street". In the past the house was beautiful and the Griersons was very rich. But in the second sentence, "garages and cotton gins" become the Actor and the focus, the "house" here is the omitted Goal, and the verbs "encroach" and "obliterate" symbolize the changes of the house. Garages and cotton gins stands for new northern industrialization which makes a sharp contrast with the old house. In the third sentence, there are two material processes. "Was left" is a passive voice, the environment of the house is changed, so the state of the house has to change accordingly. The Goal of the verb "lift" is "stubborn and coquettish decay" and "above the cotton wagons and the gasoline pumps" is the Circumstance of space. In the past, it used to be a delicate house on a select street, but now it is eyesore and surrounded by cotton wagons and the gasoline pumps. Both cotton wagons and the gasoline pumps are the outdated productive tools used in old southern agriculture which is in accordance with Emily's decayed house. This sentence presents readers the present condition of the fallen aristocrat.

Alive, Miss Emily had been a tradition, a duty, and a care; a sort of hereditary obligation upon the town (Qian, 2011, P.238).

This is a relational process, "a tradition, a duty, and a care; a sort of hereditary obligation" are the label people in this town give to Emily. In the civil war, the south is beaten by the south, so after the civil war people in the south are hard to face and adjust themselves to the great changes. They miss their old lives and they have to find a way to release their nostalgia. Since Emily is the only aristocrat in the town, it is natural for them to concern the life and behaviors of Emily. This sentence is work in concert with the sentence in the beginning "the men through a sort of respectful affection for a fallen monument, the women mostly out of curiosity to see the inside of her house". Emily is a monument because she is a representative of the past southern tradition, people show respect to her and look down upon her very much.

\section{B. Mental processes}


According to Halliday, perception like seeing, hearing, affection like fearing, liking and cognition like thinking, knowing, and understanding are subtypes of mental processes. The total number of mental processes in the story is 46. But there are only 11processes where Emily is the sensor, for most of the processes the sensors are people in the town. See Table. 2 and Table.3.

TABLE. 2

MENTAL PROCESSES

\begin{tabular}{|l|l|l|l|l|l|l|l|}
\hline Material processes & see & believe & know & look & feel & meet & think \\
\hline Number & 18 & 7 & 7 & 10 & 1 & 1 & 2 \\
\hline Proportion & $40 \%$ & $15 \%$ & $15 \%$ & $22 \%$ & $2 \%$ & $2 \%$ & $4 \%$ \\
\hline
\end{tabular}

TABLE. 3

SENSORS OF MENTAL PROCESSES

\begin{tabular}{|l|l|l|}
\hline Sensors & Emily & People in the town \\
\hline Number & 12 & 34 \\
\hline Proportion & $26 \%$ & $74 \%$ \\
\hline
\end{tabular}

The function of these mental processes can be valued through some selected processes in the whole text.

That was when people had begun to feel really sorry for her. People in our town, remembering how old lady Wyatt, her great-aunt, had gone completely crazy at last, believed that the Griersons held themselves a little too high for what they really were. None of the young men were quite good enough for Miss Emily and such. We had long thought of them as a tableau, Miss Emily a slender figure in white in the background, her father a spraddled silhouette in the foreground, his back to her and clutching a horsewhip, the two of them framed by the back-flung front door. So when she got to be thirty and was still single, we were not pleased exactly, but vindicated; even with insanity in the family she wouldn't have turned down all of her chances if they had really materialized (Qian, 2011, p.341).

In this paragraph, there are three mental processes. In the first two mental processes identified by "feel" and "believe", both the sensors are "they" which implies people in the town, but the phenomena are different and even contradictory. On one hand, people in the town have pity on Emily since she and her family "hold themselves a little too high for what they really were", on the other hand, they still respect Emily otherwise they would not think of Emily and her father as a "tableau". This can reflect people's condition after civil war, they still miss the past and traditional life and at the same time they understand the changes in the town. They are just unwilling to accept the present condition. So they have to consider Emily as the only spiritual embodiment of the past, but in fact, they do not really care Emily. In their eyes, Emily is a young lady from a tableau. She is not a fresh and lively girl in their neighborhood. She is a girl whose life is closely controlled by her father and has no choice to decide her own fate when her father was alive.

But people never stop their eyes on Emily or pay attention to what happened to her. After her father's death, Emily's life seems changes a lot.

Now she too would know the old thrill and the old despair of a penny more or less (Qian, 2011, p.341).

In this mental process, "Emily" works as the Sensor and the phenomenon is "the old thrill and the old despair of a penny more or less." There is no doubt that she begins to realize how difficult the life is. She has no one to depend on and the house her father left for her becomes her only possession. Being left alone, and a pauper, she had become humanized.

People are active to observe Emily's everything which can be concluded from the following mental sentences, especially mental processes with "see". Most of the sensors are "we".

1).SHE WAS SICK for a long time. When we saw her again, her hair was cut short, making her look like a girl, with a vague resemblance to those angels in colored church windows--sort of tragic and serene(Qian, 2011, p.342).

2).Presently we began to see him and Miss Emily on Sunday afternoons driving in the yellow-wheeled buggy and the matched team of bays from the livery stable (Qian, 2011, p.342).

3).Now and then we would see her at a window for a moment, as the men did that night when they sprinkled the lime, but for almost six months she did not appear on the streets (Qian, 2011, p.345).

4). When we next saw Miss Emily, she had grown fat and her hair was turning gray (Qian, 2011, p.345).

5).Now and then we would see her in one of the downstairs windows (Qian, 2011, p.346).

In sentence 1), when "we" see Emily, she recovers from her father's death and presents a new look before people. She cuts short her hair and looks younger. As we know women usually like to change their hairstyles when they want to end the old life and begin a new one, there is no exception for Emily. It is a big step for her to change herself actively. She starts to hold her life in her own hand and manages to rebel her tragic fate. It is not easy because her behavior is highly concerned by people in the town which can be shown in her relation with Homer. In the sentence 2), Emily is seen driving in the yellow-wheeled buggy publicly. This is really a serious breaking of southern tradition. As a lady of that time, her behavior is "a disgrace to the town and a bad example to the young people". Influenced by Puritanism and hierarchy, a lady should be religious, pure and obedient. It is impossible for noble Emily to fall in love with a normal northern worker with wages. She is crazy to her love and that is why she does so. Even though she knows clearly the bad effect of her deeds, she would like to fight for her love. But Homer is not the best choice for Emily since he doesn't want to get married. After he deserts Emily, people are still curious about Emily and this is why there are so many sentences in with "see", such as sentence 3), 4), and5), and all the sensors in the mental processes are "we". 
People not only see what happens to Emily all the time, but also guess every event with their imagination. We can draw this conclusion through the following sentences in this short story.

6). She carried her head high enough--even when we believed that she was fallen (Qian, 2011, p.343).

7). Then we knew that this was to be expected too; as if that quality of her father which had thwarted her woman's life so many times had been too virulent and too furious to die(Qian, 2011, p.345).

In the mental process of sentence 6), the phenomenon is "that she was fallen".

The word "fallen" conveys two kinds of meaning, first it refers to Emily's falling in Love River, second it can be understood as Emily's degeneration. But according to the background of the story, the second one is more reasonable, because it shows people's attitude towards Emily's love to Homer. "We" disapprove her. Compared with the material process it follows, Emily deliberately carries her head high enough. "high enough" is the circumstance to describe the position of her head which can show Emily's efforts to keep her elegance and her determination to guard her love. In sentence 7), the verb "know" is a recognition mental process which states the fact. When Homer leaves, Emily doesn't appear on the street for a long time. People know her react is quite normal. She is just out of love, and because of her father's long constraint, her love for Homer must be fervent and crazy. People seem omniscient and everything is within their mind. But actually they are wrong, Emily has already poisoned Homer to death and live with the dead body every day. All the things they know are the subjective imagination and they are the main killer of Emily's love. But on the contrary, they blame the virulent and furious character. All the mental processes of the people in the town prove that they just want to keep the monumental image of Emily to hide their inner fear.

\section{Verbal Processes}

Verbal processes also occupies high proposition and it is necessary to study the significance of them. They are identified by verb like "say", "tell", "talk" etc. the content of each saying is called verbiage. Take verbal processes with "say" in them for example. Throughout the whole story, there are 30 verbal processes with "say", but there are only two verbal processes where "Emily" is the sayer. See Table.4.

TABLE. 4

SAYERS OF VERBAL PROCESSES

\begin{tabular}{|l|l|l|}
\multicolumn{3}{l}{ SAYERS OF VERBAL PROCESSES } \\
\hline Sayer & Emily & People in the town \\
\hline Number & 4 & 26 \\
\hline Proposition & $13 \%$ & $87 \%$ \\
\hline
\end{tabular}

Emily seldom says anything to other people. When she meets the deputation, she just stands in the door and listens more. Being asked whether she has received Sheriff's notice, she says: "I received a paper, yes. See Colonel Sartoris. I have no taxes in Jefferson." No matter what they say, Emily always repeats that she has no taxes in Jefferson. It is also true when she goes to buy poison. She talks to the druggist with repeated words "I want some poison" and refuses to say tell him the actual use of the arsenic. Emily lives in her own world and she does not like to communicate with others. She keeps the shadow of past life, so she refuses to pay taxes and ignore the drug law.

The sayers of the rest processes are "we", "the druggist", "a woman" and so on. All of these sayers are people in the town and they have already formed a group.

8).So THE NEXT day we all said, "She will kill herself"; and we said it would be the best thing. When she had first begun to be seen with Homer Barron, we had said, "She will marry him." Then we said, "She will persuade him yet," because Homer himself had remarked--he liked men, and it was known that he drank with the younger men in the Elks' Club--that he was not a marrying man. Later we said, "Poor Emily" (Qian, 2011, p.344).

People concerns Emily's behaviors, guess developments and also give their opinions. Their words become big obstacle of Emily's love and their counterview flows out their words. They pity on Emily and always say "poor Emily" but they never feel that they do great harm to Emily. They keep stop Emily from loving Homer and they think it is a shame and bad example to young man. The difficulties Emily confronts with are Homer's homosexual orientation and no marriage attitude as well as people's frustration. When rumors do not function well, people ask help from the Baptist minister and Emily's relations in Alabama. To a great extent, their interference causes Emily's tragedy.

\section{Behavioral Processes and Existential Processes}

There are few behavioral processes and existential processes in the whole text. They are not as important as the former four processes. Sometimes they are used together with other processes.

9). On the first of the year they mailed her a tax notice. February came, and there was no reply (Qian, 2011, p.339).

10). But there were still others, older people, who said that even grief could not cause a real lady to forget noblesse oblige (Qian, 2011, p.342).

11). She just stood in the door and listened quietly until the spokesman came to a stumbling halt (Qian, 2011, p.339).

12). So she had blood-kin under her roof again and we sat back to watch developments (Qian, 2011, p.344).

Sentence 9) and 10) are two existential processes. "there be" is the identifier. Sentence 9) shows Emily's deliberation of not paying taxes. Sentence 10) reflects that older people believe Emily should keep the noblesse oblige and separate Homer. They still believe in the old tradition and want Emily to follow it. Sentence 11) and 12) are two behavioral processes. Taking "Emily" as the behavior, sentence 11) presents Emily's voiceless rebellion against the deputation for 
paying taxes. Sentence 12) also delivers people's excessive attention to Emily.

\section{CONCLUSION}

This paper analyzes several examples of six processes in A Rose for Emily and it is found that they function well to illustrate the theme. Emily, the embodiment of the past tradition in all people's eyes, tries to break the constraint and seeks for her own happiness. Her love to Homer is so fervent, especially before the strong interference of people in her town, that she kills Homer and lives with him for the rest of her life. Her behavior seems abnormal but it can be understood as her helpless struggle. The continuous rumors, excessive concerns and strong disapproval given by the people become big burden to Emily. They place their hope on Emily, which can be concluded from the numerous mental processes and verbal processes. People in the town, together with Emily's father are the real causes of Emily's tragedy. All of them obey the traditional values: Puritanism, patriarchy and inhuman doctrine of woman. When the civil war ended, they depend on Emily to reveal their fear. Faulkner gives A Rose for Emily; it is a way to memorize her passing away firstly, to pity this aristocrat's tragic life secondly and finally to solute for her brave struggle against old tradition.

\section{REFERENCES}

[1] Chang Yaoxin. (2003). A Survey of American Literature the $2^{\text {nd }}$ Edition. Tianjin: Nankai University Press.

[2] He Qiong. (2010). Southern Complex and A Rose for Emily. The World Literature Criticism, 01, 121-124.

[3] Hu Zhuanglin \& Jiang Wangqi. (2002). Linguistics: An Advanced Course Book. Beijing: Peking University Press.

[4] Hu Zhuanglin \& Zhu Yongsheng \& Zhang Delu \& Li Zhanzi. (2008). Systemic Functional Linguistics (revised edition). Beijing: Peking University Press.

[5] Qian Qing. (2011).Highlights of American Literature. Beijing: Foreign Language Teaching and Research Press.

Zijiao Song, born in Tonghua, Jilin Province, China on January 8 th, 1988, is a graduate who majors in foreign linguistics and applied linguistics from School of Foreign Languages from Changchun University of Science and Technology, Changchun, Jilin Province, China. 